inadvertent tracheobronchial intubation, ${ }^{2}$ pneumothorax ${ }^{3}$ and bronchopleural fistula. ${ }^{4}$ Displacement of the tube during feeding may cause aspiration pneumonia.

Weighted tubes have a lower risk of misplacement and displacement but are more difficult to pass in uncooperative patients. The complication reported here was potentially serious. We do not know of any previous reports of difficulty in removing a nasogastric tube or of the tube breaking.

The manufacturers (Vidomedex) admit that removal can be difficult and suggest that the nostril should be examined before the tube is passed. If difficulty is encountered during removal they suggest trying to advance the tube again, retrieve the weight from the pharynx, cut it off, and remove it through the mouth. The firm impaction of the weight made subsequent advance or withdrawal of the tube impossible in our patient.

It is easy to see how the weight could become lodged behind a septal spur or a turbinate bone on removal. In such cases we therefore agree with the manufacturers' advice that per oral removal should be tried. In a patient with a narrow nostril a tube without a weight passed over a guidewire may be safer.

1 James RM. An unusual complication of passing a narrow bore nasogastric tube. Anaesthesi 1978;33:716-8.

2 Stark P. Inadvertent nasogastric tube insertion into the tracheo-bronchial tree. Radiolog 1982;142:239-40.

3 Eldar S, Meguid MM. Pneumothorax following attempted nasogastric intubation for nutritional support. Fournal of Parenteral and Enteral Nutrition 1984;8:450-2.

4 Sheffner SE, Gross BM, Birnberg FA, Birk P. Iatrogenic bronchopleural fistula caused by feeding tube insertion. I Can Assoc Radiol 1985;36:52-5.

5 Metheny NA, Spiers M, Eisenberg P. Frequency of naso-enteral tube displacement and associated risk factors. Res Nurs Health 1986;9:241-7.

(Accepted 27 Fanuary 1988)

Regional Department of Thoracic Surgery, East Birmingham Hospital, Birmingham B9 5ST

NC HICKEY, MB, CHB, registrar in thoracic surgery

DCT WATSON, FRCS, consultant thoracic surgeon

Correspondence to: Miss D C T Watson.

\section{Skeletal muscle necrosis in severe falciparum malaria}

We report skeletal muscle necrosis in a patient with severe falciparum malaria. The patient developed myoglobinuria and acute renal failure. So far as we know this complication of falciparum malaria has not previously been described.

\section{Case report}

A previously healthy 17 year old youth was admitted complaining of fever without rigors for four days, severe muscle pains associated with the passage of dark red urine for two days, and reduced urine output for one day. He had visited an area endemic for malaria two weeks before admission. There was no history of contact with heavy metals, trauma, convulsions, strenuous exercise, injections, insect stings, or snakebite or a past history of malaria. He did not drink alcohol or abuse narcotics and had not taken any medicines. He was feverish $\left(39^{\circ} \mathrm{C}\right)$ and jaundiced with generalised muscle tenderness and minimal hepatosplenomegaly. Physical examination showed no other abnormality. Urine output was 0.4 during the first day in hospital.

\section{INVESTIGATIONS AND TREATMENT}

The blood film showed asexual forms of Plasmodium falciparum $\left(9 \times 10^{\circ}\right.$ infected red cells/l). There was myoglobinuria, bilirubinuria, and mild albuminuria but no haemoglobinuria. The urine deposit contained granular casts but no haemosiderin. Haemoglobin concentration was $118 \mathrm{~g} / 1$. Packed cell volume and blood cell counts were normal, with no evidence of haemolysis. Erythrocyte sedimentation rate was $110 \mathrm{~mm}$ in the first hour, plasma urea concentration $39.8 \mathrm{mmo} / \mathrm{l}$, serum creatinine concentration $795.6 \mu \mathrm{mol} / 1$, urinary sodium excretion $58 \mathrm{mmol} / \mathrm{l}$, urine urea: plasma urea ratio 1.85 , and serum potassium concentration $6.2 \mathrm{mmol} / \mathrm{l}$. Serum sodium, calcium, and phosphate values were normal. Serum bilirubin was $102 \mu \mathrm{mol} / 1$ (conjugated bilirubin $93.3 \mu \mathrm{mol} / \mathrm{l}$ ), serum alkaline phosphatase activity $170 \mathrm{IU} /$ (normal 20-100), prothrombin time 12 seconds (ratio 1 ), plasma fibrinogen concentration $2.5 \mathrm{~g} / 1$, serum alanine transaminase activity $44 \mathrm{IU} / 1$, serum aspartate transaminase activity $130 \mathrm{IU} / \mathrm{l}$, and serum creatine kinase activity 308 IU/l (normal 10-80). Quadriceps muscle biopsy showed foci of muscle fibre necrosis with mononuclear cell infiltration (figure). Liver biopsy showed centrizonal cholestasis without necrosis or cell infiltration.
The following investigations gave negative or normal results: electrocardiograhy, chest $x$ ray, blood culture, blood and urine culture for leptospira, Wida reaction and clot culture for salmonella, Paul-Bunnell test, paired serum samples for antibodies against dengue (type 1 to 4 ), Japanese encephalitis, Coxsackie B (types 1 to 6), viruses, and leptospira, serum for hepatitis B surface antigen, serum proteins, antinuclear factor, and Coombs test.

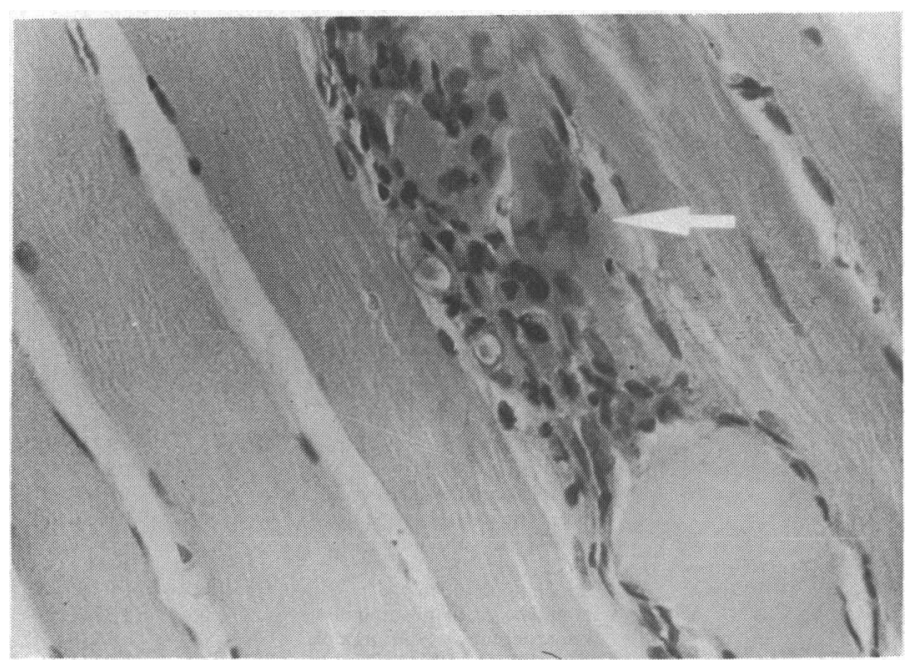

Skeletal muscle biopsy sample showing necrosis and fragmentation (arrowed) with mononuclear cell infiltrate. (Haematoxylin and eosin.)

The patient was given a four day course of chloroquine and was haemodialysed for hyperkalaemia and acute renal failure. The fever settled on the third day of treatment and he was discharged after 17 days in hospital. One month later he was symptom free.

\section{Comment}

This patient had severe falciparum malaria ${ }^{1}$ with skeletal muscle necrosis. This may have been due to sequestration of parasitised erythrocytes, causing microcirculatory obstruction, ${ }^{2}$ though immune and toxic mechanisms cannot be excluded. The onset of oliguria soon after developing myoglobinuria suggested myoglobin as a possible cause of acute rena failure, especially as there was no hypovolaemia or intravascular haemolysis. Parasite sequestration, ${ }^{1}$ however, may have been another contributory factor.

Hepatic dysfunction, as found in our patient, may occur in falciparum malaria. ${ }^{34}$ The histological picture varies from normal or slight hepatocyte swelling ${ }^{5}$ to hepatocyte necrosis with mononuclear cell infiltration. Cholestasis without necrosis, however, has not been reported

We thank Drs S Ramachandran and C A Herath for the haemodialysis.

World Health Organisation Malaria Action Programme. Severe and complicated malaria. Trans $R$ Soc Trop Med Hyg 1985;80(suppl): 1-50.

2 Miller LH, Usami S, Chien J. Alteration in the rheologic properties of Plasmodium knowlesi infected red cells, a possible mechanism for capillary obstruction. $\mathcal{F}$ Clin Invest 1972;50:1451-5. 3 Patwari A, Aneja S, Berry A, Ghosh S. Hepatic dysfunction in childhood malaria. Arch Dis Child 1979;54:139-41.

4 Ramachandran S, Perera MVF. Jaundice and hepatomegaly in primary malaria. $\mathcal{F}$ Trop Med Hyg 1976;79:207-10

5 Sherlock S. Diseases of the liver and biliary systems. Oxford: Blackwell Scientific, 1985.

(Accepted 23 December 1987)

General Hospital, Colombo, Sri Lanka

H J DE SILVA, MD, assistant physician

A K E GOONETILLEKE, MB, BS, senior house office

N SENARATNA, MB, BS, senior house officer

N RAMESH, MB, BS, house officer

U S JAYAWICKRAMA, MD, FRCP, consultant physician

Faculty of Medicine, Colombo 8, Sri Lanka

K S A JAYASINGHE, MD, MRCP, lecturer in medicine

L R AMARASEKERA, MB, PHD, senior lecturer in pathology

Correspondence to: Dr H J De Silva, Department of Gastroenterology, The Radcliffe Infirmary, Oxford OX2 6HE 